\title{
Physical and Chemical Properties of Sandy Soil as Influenced by the Application of Hydrogel and Mulching in Maize (Zea mays L.)
}

\author{
R. Shiva Kumar*, T.K. Bridgit and A. Chanchala \\ Department of Agronomy, College of Agriculture, Padannakkad, Kerala Agricultural \\ University, Thrissur, Kerala, India \\ *Corresponding author
}

\begin{abstract}
A B S T R A C T
Keywords

Hydrogel, Rice straw mulch, Rice husk mulch, Coirpith compost mulch, Porosity, Bulk density and Available soil N, $\mathrm{P}_{2} \mathrm{O}_{5}$ and $\mathrm{K}_{2} \mathrm{O}$

Article Info

Accepted:

26 June 2018

Available Online:

10 July 2018

A field experiment was conducted at College of Agriculture, Padannakkad, Kerala Agricultural University, Thrissur, Kerala, India to study the effect of hydrogel (super absorbent polymer) and mulching on physical and chemical properties of sandy soil in maize (Zea mays L.). The experiment was conducted in factorial randomized block design having two factors with three levels each and one additional control. Different levels of hydrogel and types of mulches, their interactions and a control were analysed statistically on physical properties of soil like porosity and bulk density and chemical properties like available soil N, $\mathrm{P}_{2} \mathrm{O}_{5}$ and $\mathrm{K}_{2} \mathrm{O}$. Results revealed that main effects of hydrogel applied @ $3.75 \mathrm{~kg} \mathrm{ha}^{-1}$ and coirpith compost mulch @ $2.5 \mathrm{t} \mathrm{ha}^{-1}$ recorded the maximum soil porosity. The residual nutrient status with respect to available soil $\mathrm{N}$ and $\mathrm{K}_{2} \mathrm{O}$ recorded maximum with main and interaction effects of treatments contain hydrogel @ $1.25 \mathrm{~kg} \mathrm{ha}^{-1}$ and rice husk mulch@5 tha ${ }^{-1}$ and available soil $\mathrm{P}_{2} \mathrm{O}_{5}$ was recoded maximum with hydrogel @ $3.75 \mathrm{~kg} \mathrm{ha}^{-1}$ and rice husk mulch @ $5 \mathrm{t} \mathrm{ha}^{-1}$. Control recorded the high available soil N, $\mathrm{P}_{2} \mathrm{O}_{5}, \mathrm{~K}_{2} \mathrm{O}$ content than the remaining treatments.
\end{abstract}

\section{Introduction}

Maize (Zea mays L) is one of the most versatile crop having capacity to adapt under different agro-climatic conditions (Kogbe and Adediran, 2003), with altitudinal ranges of 0 to 3000 meters above the mean sea level. Generally, maize is known as "queen of cereals" because it has the highest genetic yield potential among the cereals. In India, maize is the third most important food crop after rice and wheat. In addition to staple food for human being and quality feed for animals, maize serves as a basic raw material for thousands of industrial products like starch, oil, protein, alcoholic beverages, food sweeteners, pharmaceuticals, cosmetics, film, textile, gum, package and paper industries etc.

According to Wallace (2000), presently 80 per cent of water resources are available in the world for supporting irrigated agriculture. As resources of water decreases, water saving agriculture is required for the sustainable growth of human societies. Besides, due to 
climate changes droughts are predicted to increase. So it is the need of the hour to adopt different practices to improve the crop production under water scares condition (Gornall et al., 2010). In present experiment a new technology which is hydrogel and an old technology which is mulching with different organic mulches were used for conservation of moisture in the soil.

Less moisture retaining capability, less fertility and high percolation losses of soil moisture caused the less crop productivity in sandy soils and finally reduced moisture and nutrient use efficiency (Rigas et al., 1999; Sivapalan, 2006). Hydrogel absorbs 20 times more water than its own weight. Because of the improvement of a more cross-linked polymer having more water holding capacity (400 to 2000 times than its weight) and its less cost has revived interest on the utilization of hydrogel in Agriculture. Several studies have been focused on the efficacy of hydrogel uses in sandy soils and in soils of desert areas. Hydrogel prolongs the plant nutrient and water uptake by releasing the water slowly over a longer period. It decreases the water usage and improves the physical properties of the soil. Moreover, this may be providing accurate entry to essential nutrients for plant growth and thus the biomass production was noticeably improved (Gunes et al., 2016).

Hydrogel improved the physical condition of soils like porosity, bulk density, water holding capacity, soil permeability, infiltration rate, etc. Improvement of porosity causes the enhancement in seed germination, seedling emergence rate, root growth. It also improved biological/microbial activities in the soil, that enhanced the air accessibility in root zone of plants (Dar et al., 2017).

According to Mbagwu (1989), organic wastes application decreases soil apparent specific gravity and enhances total porosity of soil.
Crop residue mulch application @ 4 and $6 \mathrm{t}$ $\mathrm{ha}^{-1}$ improved chemical and physical properties of the soil and finally increased grain yield of the crop (Bhatt et al., 2004; Khurshid et al., 2006). Mulching offers an improved soil environment, controls soil temperature, enhances soil porosity and water infiltration rate at severe rain and maintains runoff and erosion besides it supress weeds development (Anikwe et al., 2007; Glab and Kulig, 2008). Besides preserving water and preventing erosion, mulching also enhanced the soil flora and fauna, supress weeds growth and maintains maximum crop productivity (Essien et al., 2009). The other findings proved that rice husk upgraded soil physical properties and which improves the corn grain yield. Porosity significantly changes moisture circulation and air exchange in soil (Uguru et al., 2015).

\section{Materials and Methods}

The experiment was conducted at College of Agriculture, Padannakkad, Kerala Agricultural University, Thrissur, Kerala, India. Soil of experimental field is sandy. The experiment was laid out in factorial randomized block design having two factors with three levels each and one additional control. Hydrogel and mulch were the two factors. Three levels of hydrogel $\mathrm{H}_{1}-1.25 \mathrm{~kg} \mathrm{ha}^{-1}, \mathrm{H}_{2}-2.5 \mathrm{~kg} \mathrm{ha}^{-1}$, $\mathrm{H}_{3}-3.75 \mathrm{~kg} \mathrm{ha}^{-1}$ and three types of mulch $\mathrm{M}_{1}$ - rice straw mulch, $\mathrm{M}_{2}$ - rice husk mulch, $\mathrm{M}_{3}$ - Coir pith compost mulch were tested in the study. Straw mulch and rice husk mulch was applied@5 t ha ${ }^{-1}$ and coir pith compost mulch was applied @ $2.5 \mathrm{t} \mathrm{ha}^{-1}$.The treatment combinations were $\mathrm{T}_{1}-1.25 \mathrm{~kg} \mathrm{ha}^{-1}$ hydrogel + rice straw mulch, $\mathrm{T}_{2}-1.25 \mathrm{~kg} \mathrm{ha}^{-1}$ hydrogel + rice husk mulch, $\mathrm{T}_{3}-1.25 \mathrm{~kg} \mathrm{ha}^{-1}$ hydrogel + Coir pith compostmulch, $\mathrm{T}_{4}-2.5 \mathrm{~kg} \mathrm{ha}^{-1}$ hydrogel + rice strawmulch, $\mathrm{T}_{5}-2.5 \mathrm{~kg} \mathrm{ha}^{-1}$ hydrogel + rice huskmulch, $\mathrm{T}_{6}-2.5 \mathrm{~kg} \mathrm{ha}^{-1}$ hydrogel + coir pith compostmulch, $\mathrm{T}_{7}-3.75$ $\mathrm{kg} \mathrm{ha}^{-1}$ hydrogel + rice strawmulch, $\mathrm{T}_{8}-3.75$ 
$\mathrm{kg} \mathrm{ha}^{-1}$ hydrogel + rice huskmulch, $\mathrm{T}_{9}-3.75$ $\mathrm{kg} \mathrm{ha}^{-1}$ hydrogel + coir pith compostmulch, $\mathrm{T}_{10}$ - control (without hydrogel and mulch). Before the start of experiment to all the treatments an equal amount of FYM was applied @ $25 \mathrm{t} \mathrm{ha}^{-1}$. Fertilizers were applied @ 135:65:15N, $\mathrm{P}_{2} \mathrm{O}_{5}, \mathrm{~K}_{2} \mathrm{O} \mathrm{kg} \mathrm{ha}{ }^{-1}$ respectively. Nitrogen was applied in three equal doses, first as basal, second at knee high stage and third at tasseling stage. Full dose of $\mathrm{P}_{2} \mathrm{O}_{5}$ and half dose of potassium was applied as basal and the remaining half dose of $\mathrm{K}_{2} \mathrm{O}$ was applied at tasseling stage along with $\mathrm{N}$. The observations were recorded at harvest stage on soil physical properties like bulk density and porosity and the chemical properties like available soil $\mathrm{N}, \mathrm{P}_{2} \mathrm{O}_{5}$ and $\mathrm{K}_{2} \mathrm{O}$. The methods adopted for estimation of physical and chemical properties of soil are presented in the Table 1.

\section{Results and Discussion}

\section{Bulk density}

The data on bulk density of soil at harvest stage of maize crop (Table 2 and 3), indicated that there was no significant difference among the levels of hydrogel, types of mulches, their interactions and between control and other treatments.

\section{Porosity}

The data on porosity of soil at harvest of the crop are presented in Table 2 and 3. The results showed that porosity of soil was significantly influenced by levels of hydrogel and types of mulch and no significant difference was observed between interactions of levels of hydrogel and types of mulch and control versus other treatments.

Among the levels of hydrogel, maximum porosity was observed in hydrogel applied @ $3.75 \mathrm{~kg} \mathrm{ha}^{-1}(43.64 \%)$ which was significantly superior to other levels of hydrogel @ $2.5 \mathrm{~kg}$ $\mathrm{ha}^{-1}$ and $1.25 \mathrm{~kg} \mathrm{ha}^{-1}$. Generally sandy soil has less porosity than the fine textured soils though it contains large pores. Increased porosity of soil with increase in the hydrogel dose might be due to occupying of large sandy soil pores with hydrogel. Increased porosity of soil due to hydrogel application was also observed by Uz et al., (2008). Among the types of mulch, maximum porosity was observed with coirpith compost mulch @ $2.5 \mathrm{t}$ $\mathrm{ha}^{-1}(43.56 \%)$ which was significantly superior to rice straw and rice husk mulch. The maximum porosity was observed in case of coirpith compost mulch than other two types of mulch might be due to fine texture of coir pith compost and was mixed well with sandy soil than the other two types of mulches viz. rice straw mulch and rice husk mulch. The microbial decomposition products of organic mulches such as polysaccharides and bacterial gums are known to act as soil particle binding agents. These binding agents improve soil aggregation and hence increase the porosity (Bhatia and Shukla, 1982). Increase in the porosity of soil due to mulching was observed by Uguru et al., (2015). Porosity of soil revealed no significant difference among the interaction effects of levels of hydrogel and types of mulches and when comparing the control with rest of treatments.

\section{Available soil N}

Available soil $\mathrm{N}$ content was significantly influenced by the levels of hydrogel, types of mulch, their interactions and control versus other treatments (Table 2 and 3). Among the levels of hydrogel, hydrogel applied @ 1.25 $\mathrm{kg} \mathrm{ha}^{-1}\left(238.34 \mathrm{~kg} \mathrm{ha}^{-1}\right)$ recorded higher available soil $\mathrm{N}$ content than other two levels of hydrogel @ $2.5 \mathrm{~kg} \mathrm{ha}^{-1}$ and $3.75 \mathrm{~kg} \mathrm{ha}^{-1}$. Among types of mulch, rice husk mulch @ $5 \mathrm{t}$ $\mathrm{ha}^{-1}\left(236.94 \mathrm{~kg} \mathrm{ha}^{-1}\right)$ recorded higher available soil $\mathrm{N}$ content followed by coirpith compost @ $2.5 \mathrm{t} \mathrm{ha}^{-1}$ which was on par and superior to 
rice straw mulch. Among the interactions, $\mathrm{kg} \mathrm{ha}^{-1}$ with coirpith compost mulch @ $2.5 \mathrm{t}$ hydrogel applied @ $1.25 \mathrm{~kg} \mathrm{ha}^{-1}$ with rice $\mathrm{ha}^{-1}$ and superior to other interactions. When husk mulch @ $5 \mathrm{t} \mathrm{ha}^{-1}\left(246.70 \mathrm{~kg} \mathrm{ha}^{-1}\right)$ control was compared with other treatments, recorded maximum available soil $\mathrm{N}$ content control recorded higher soil nitrogen content and was on par with hydrogel applied @ 2.5 of soil than the other treatments.

Table.1 The methods adopted for estimation of physical and chemical properties of soil

\begin{tabular}{|c|c|c|c|}
\hline $\begin{array}{l}\text { S. } \\
\text { No. }\end{array}$ & Parameters & Method used & Refernce \\
\hline 1. & Bulk density $\left(\mathrm{g} \mathrm{cc}^{-1}\right)$ & $\begin{array}{l}\text { Undisturbed core sample } \\
\text { method }\end{array}$ & Black et al., (1965) \\
\hline 2. & Particle density $\left(\mathrm{g} \mathrm{cc}^{-1}\right)$ & Pycnometer method & Black et al., (1965) \\
\hline 3. & Available $\mathrm{N}\left(\mathrm{kg} \mathrm{ha}^{-1}\right)$ & Alkaline permanganate method & $\begin{array}{l}\text { Subbiah and Asija, } \\
\text { (1956) }\end{array}$ \\
\hline 4. & Available $\mathrm{P}_{2} \mathrm{O}_{5}\left(\mathrm{~kg} \mathrm{ha}^{-1}\right)$ & $\begin{array}{l}\text { Bray extraction and } \\
\text { photoelectric colorimetry }\end{array}$ & Jackson, (1958) \\
\hline 5. & Available $\mathrm{K}_{2} \mathrm{O}\left(\mathrm{kg} \mathrm{ha}^{-1}\right)$ & Ammonium acetate method & Jackson, (1973) \\
\hline
\end{tabular}

Table.2 Main effect of hydrogel and mulching in bulk density $\left(\mathrm{g} \mathrm{cc}^{-1}\right)$, porosity (\%) and nutrient content of soil $\left(\mathrm{kg} \mathrm{ha}^{-1}\right)$

\begin{tabular}{|c|c|c|c|c|c|}
\hline Treatment & $\begin{array}{c}\text { Bulk density } \\
\text { of soil } \\
\begin{array}{c}\text { Level of } \\
\text { hydrogel }\end{array}\end{array}$ & $\begin{array}{c}\text { Porosity of } \\
\text { soil }(\%)\end{array}$ & \multicolumn{3}{|c|}{ Available nutrient content of soil $\left(\mathrm{kg} \mathrm{ha}^{-1}\right)$} \\
\hline $\left.\mathrm{H}_{1}\right)$ & & $\mathbf{N}$ & $\mathbf{P}_{\mathbf{2}} \mathbf{O}_{\mathbf{5}}$ & $\mathbf{K}_{\mathbf{2}} \mathbf{O}$ \\
\hline $\mathrm{H}_{2}$ & 1.43 & 42.93 & 238.34 & 64.63 & 276.12 \\
\hline $\mathrm{H}_{3}$ & 1.42 & 43.20 & 232.76 & 62.47 & 230.27 \\
\hline $\mathrm{SEm}( \pm)$ & 0.013 & 0.159 & 1.958 & 1.197 & 9.167 \\
\hline $\mathrm{CD}(0.05)$ & $\mathrm{NS}$ & 0.334 & 4.114 & 2.515 & 19.260 \\
\hline Types of mulch & & & & & \\
\hline $\mathrm{M}_{1}$ & 1.42 & 43.07 & 204.89 & 55.91 & 200.55 \\
\hline $\mathrm{M}_{2}$ & 1.42 & 43.16 & 236.94 & 76.97 & 268.29 \\
\hline $\mathrm{M}_{3}$ & 1.41 & 43.56 & 234.15 & 62.24 & 239.98 \\
\hline SEm $( \pm)$ & 0.013 & 0.159 & 1.958 & 1.197 & 9.167 \\
\hline $\mathrm{CD}(0.05)$ & $\mathrm{NS}$ & 0.334 & 4.114 & 2.515 & 19.260 \\
\hline
\end{tabular}


Table.3 Interaction effect of hydrogel and mulching in bulk density $\left(\mathrm{g} \mathrm{cc}^{-1}\right)$, porosity $(\%)$ and nutrient content of soil $\left(\mathrm{kg} \mathrm{ha}^{-1}\right)$

\begin{tabular}{|c|c|c|c|c|c|}
\hline \multirow{2}{*}{$\begin{array}{c}\text { Treatment } \\
\text { Interactions }\end{array}$} & \multirow{2}{*}{$\begin{array}{l}\text { Bulk density of } \\
\text { soil }\left(\mathrm{g} \mathrm{cc}^{-1}\right)\end{array}$} & \multirow{2}{*}{$\begin{array}{l}\text { Porosity } \\
\text { of soil (\%) }\end{array}$} & \multicolumn{3}{|c|}{ Available nutrient content of soil $\left(\mathrm{kg} \mathrm{ha}^{-1}\right)$} \\
\hline & & & $\mathbf{N}$ & $\mathbf{P}_{2} \mathbf{O}_{5}$ & $\mathrm{~K}_{2} \mathrm{O}$ \\
\hline $\mathrm{H}_{1} \mathrm{M}_{1}$ & 1.43 & 42.80 & 234.15 & 58.56 & 223.10 \\
\hline $\mathrm{H}_{1} \mathrm{M}_{2}$ & 1.43 & 42.80 & 246.70 & 72.50 & 319.42 \\
\hline $\mathrm{H}_{1} \mathrm{M}_{3}$ & 1.42 & 43.20 & 234.15 & 62.84 & 285.82 \\
\hline $\mathrm{H}_{2} \mathrm{M}_{1}$ & 1.43 & 42.80 & 217.43 & 48.65 & 192.64 \\
\hline $\mathrm{H}_{2} \mathrm{M}_{2}$ & 1.41 & 43.47 & 238.34 & 72.58 & 246.40 \\
\hline $\mathrm{H}_{2} \mathrm{M}_{3}$ & 1.42 & 43.33 & 242.52 & 66.17 & 251.78 \\
\hline $\mathrm{H}_{3} \mathrm{M}_{1}$ & 1.41 & 43.60 & 163.07 & 60.53 & 185.92 \\
\hline $\mathrm{H}_{3} \mathrm{M}_{2}$ & 1.42 & 43.20 & 225.79 & 85.84 & 239.05 \\
\hline $\mathrm{H}_{3} \mathrm{M}_{3}$ & 1.40 & 44.13 & 225.79 & 57.71 & 182.34 \\
\hline $\operatorname{SEm}( \pm)$ & 0.022 & 0.275 & 3.391 & 2.073 & 15.878 \\
\hline $\mathrm{CD}(0.05)$ & $\mathrm{NS}$ & $\mathrm{NS}$ & 7.125 & 4.356 & 33.359 \\
\hline \multicolumn{6}{|c|}{ Control vs other treatments } \\
\hline control & 1.41 & 43.47 & 250.88 & 85.94 & 323.71 \\
\hline $\operatorname{SEm}( \pm)$ & 0.016 & 0.205 & 2.528 & 1.545 & 11.835 \\
\hline $\mathrm{CD}(0.05)$ & NS & NS & 5.311 & 3.247 & 24.864 \\
\hline
\end{tabular}

\section{Available soil $\mathbf{P}_{2} \mathrm{O}_{5}$}

Available soil $\mathrm{P}_{2} \mathrm{O}_{5}$ content was significantly influenced by the levels of hydrogel, types of mulch, their interactions and control versus other treatments (Table 2 and 3). Among the levels of hydrogel, maximum available soil $\mathrm{P}_{2} \mathrm{O}_{5}$ content was observed with hydrogel level @ $3.75 \mathrm{~kg} \mathrm{ha}^{-1}\left(68.02 \mathrm{~kg} \mathrm{ha}^{-1}\right)$ which was significantly superior to other two levels of hydrogel@2.5 kg ha ${ }^{-1}$ and $3.75 \mathrm{~kg} \mathrm{ha}^{-1}$. Among the types of mulch, maximum available soil $\mathrm{P}_{2} \mathrm{O}_{5}$ content was observed with rice husk mulch @ $5 \mathrm{t} \mathrm{ha}^{-1}\left(76.97 \mathrm{~kg} \mathrm{ha}^{-1}\right)$ which was significantly superior to rice straw and coirpith compost mulch. With respect to interactions, hydrogel applied @ $3.75 \mathrm{~kg} \mathrm{ha}^{-1}$ with rice husk mulch@5 t ha-1 $(85.84 \mathrm{~kg}$ ha ${ }^{-1}$ ) recorded maximum available soil $\mathrm{P}_{2} \mathrm{O}_{5}$ content and was significantly superior to other combinations. When compared the control with other treatments, control recorded higher available soil $\mathrm{P}_{2} \mathrm{O}_{5}$ content of than the other treatments.

\section{Available soil $\mathrm{K}_{2} \mathrm{O}$}

The effect of hydrogel and mulching on available soil $\mathrm{K}_{2} \mathrm{O}$ content (Table 2 and 3) indicated that potassium content was significantly influenced by the levels of hydrogel, types of mulch, their interactions and control versus other treatments. Among the levels of hydrogel, maximum available soil $\mathrm{K}_{2} \mathrm{O}$ content was observed in hydrogel @ $1.25 \mathrm{~kg} \mathrm{ha}^{-1}\left(276.12 \mathrm{~kg} \mathrm{ha}^{-1}\right)$ which was 
significantly superior to other two levels of hydrogel. Among the types of mulch maximum available soil $\mathrm{K}_{2} \mathrm{O}$ content was recorded by rice husk mulch @ $5 \mathrm{t} \mathrm{ha}^{-1}$ $\left(268.29 \mathrm{~kg} \mathrm{ha}^{-1}\right)$ and was significantly superior to other two types of mulch. With respect to interactions, hydrogel applied @ $1.25 \mathrm{~kg} \mathrm{ha}^{-1}$ with rice husk mulch @ $5 \mathrm{t} \mathrm{ha}^{-1}$ (319.42 $\mathrm{kg} \mathrm{ha}^{-1}$ ) recorded maximum available soil $\mathrm{K}_{2} \mathrm{O}$ content which was on par with hydrogel applied @ $1.25 \mathrm{~kg} \mathrm{ha}^{-1}$ with coirpith compost mulch@5 t ha ${ }^{-1}$ and superior to other combinations.

When control was compared with other treatments, control recorded higher available soil $\mathrm{K}_{2} \mathrm{O}$ content than the other treatments.

From the above results on available soil N, $\mathrm{P}_{2} \mathrm{O}_{5}, \mathrm{~K}_{2} \mathrm{O}$, among the types of mulch, rice husk mulch@5 t ha ${ }^{-1}$ showed high content of available soil $\mathrm{N}, \mathrm{P}_{2} \mathrm{O}_{5}, \mathrm{~K}_{2} \mathrm{O}$ than other types of mulch. Though rice husk is applied as a mulch, it will take more time to degrade due to wide $\mathrm{C}$ : $\mathrm{N}$ ratio and high silica content. Part of the applied nutrients and the nutrients available from the soil may be utilized for decomposition of rice husk and might be retained in the soil.

High available soil $\mathrm{N}$ and $\mathrm{K}_{2} \mathrm{O}$ content was recorded when hydrogel was applied @ 1.25 $\mathrm{kg} \mathrm{ha}^{-1}$ and high available $\mathrm{P}_{2} \mathrm{O}_{5}$ recorded when hydrogel was applied @ $3.75 \mathrm{~kg} \mathrm{ha}^{-1}$ it might be due to hydrogels usually contain micro pores that allow small molecules such as $\mathrm{NH}_{4}$ to diffuse through the hydrogel. The subsequent release of nutrient is then based on the diffusive properties of the polymer, its decomposition rate, and the nature of the nutrient salt (Johnson and Veltkamp, 1985). Control recorded high available soil $\mathrm{N}, \mathrm{P}_{2} \mathrm{O}_{5}$, $\mathrm{K}_{2} \mathrm{O}$ content than the remaining treatments because less uptake of these nutrients in control plot due to poor growth of the plant.

\section{References}

Anikwe, M. A. N., Mbah, C. N., Ezeaku, P. I. and Onyia, V. N. 2007. Tillage and plastic mulch effects on soil properties and growth and yield of cocoyam (Colocasia esculenta) on an ultisol in South Eastern Nigeria. Soil Tillage Res. 93: 264-273.

Bhatia, K. S. and Shukla, K. K. 1982. Effect of continuous application of fertilizers and manure on some physical properties of eroded alluvial soil. J. Indian Soc. of Soil Science. 30: 33-36.

Bhatt, R., Khera, K. L. and Arora, S. 2004. Effect of tillage and mulching on yield of corn in the sub mountainous rainfed of Punjab, India. Int. J. Agric. Biol. 6(1): 126-128.

Black, C. A., Evans, D. D., Ensminger, L. E., White, J. L. and Clark, F. E. 1965. Methods of soil analysis. American Society of Agronomy, USA, 156p.

Dar, S. B., Mishra, D., Zahida, R., and Afshana, B. B. 2017. Hydrogel: To enhance crop productivity per unit available water under moisture stress Agriculture. Bull. Env. Pharmacol. Life Sci. 6(10): 129-135.

Essien, B. A., Essien, J. B., Nwite, J. C., Eke, K. A.,Anaele, U. M. andOgbu, J. U.2009. Effect of organic mulch materials on maize performance and weed growth in the derived savannah of South Eastern Nigeria. Niger. Agric. J. 40(1): 255-262.

Glab, T. and Kulig, B. 2008. Effect of mulch and tillage system on soil porosity under wheat (Triticum aestivum). Soil Tillage Res. 99: 169-178.

Gornall, J., Betts, R., Burke, E., Clark, R., Camp, J., Willett, K. and Wiltshire, A. 2010. Implications of climate change for agricultural productivity in the early twenty-first century. Philos. Trans. R. Soc. Biol. Sci. 365: 2973- 
2989.

Gunes, A., Kitir, N., Turan, M., Elkoa, E., Yildirim, E. and Avci, N. 2016. Evaluation of effects of water-saving superabsorbent polymer on corn (Zea mays L.) yield and phosphorus fertilizer efficiency. Turkish J. Agric. For. 40: 365-378.

Jackson, M. L. 1958. Soil chemical analysis (Indian Reprint, 1967). Prentice Hall of India, New Delhi, 498p.

Jackson, M. L. 1973. Soil chemical analysis $\left(2^{\text {nd }}\right.$ Ed.). Prentice Hall of India, New Delhi, 498p.

Johnson, M. S. and Veltkamp, C. J. 1985. Structure and functioning of water storing agricultural polyacrylamides. J. Sci. Food Agric. 36: 789-793.

Khan, M. A. H. and Parvej, M. R. 2010. Impact of conservation tillage under organic mulches on the reproductive efficacy and yield of Quality Protein Maize. J. Agric. Sci. 5(2): 52-63.

Khurshid, K., Iqbal, M., Arif, M. S. and Nawaz, A. 2006. Effect of tillage and mulch on soil physical properties and growth of maize. Int. J. Agric. Biol. 8(5): 593-596.

Kogbe J. O. S. and Adediran J. A. 2003. Influence of nitrogen, phosphorus and potassium application on the yield of maize in the Savanna zone of Nigeria. Afr. J. Biotechnol. 2(10): 345-349.

Rigas, F., Sachini, E., Chatzoudis, G. and Kanellopoulos, N. 1999. Effects of a polymeric soil conditioner on the early growth of sunflowers. Can. J. Soil Sci. 79: 225-231.

Mbagwu, J. S. C. 1989. Influence of organic amendment on some physical properties of tropical Ultisol. Biol. Waste 27: 1-133.

Sivapalan, S. 2006. Benefits of treating a sandy soil with a cross linked type polyacrylamide. Aust. J. Exp. Agric. 46: 579-584.

Subbiah, B. V. and Asija, G. L. A. 1956. A rapid procedure for the estimation of available nitrogen in soil. Curr. Sci. 32: 325-327.

Uguru, B. N., Mbah, C. N. and Njoku, C. 2015. Effect of rice husk dust on selected soil physical properties and maize grain yield in Abakaliki, South Eastern Nigeria. Glob. Adv. Res. J. Agric. Sci. 4(12): 878-886.

Uz, B. Y., Sabit, E., Demiray, E. and Erta, E. 2008. Analysing the soil texture effect on promoting water holding capacity by polyacrylamide. In: International Meeting On 'Soil Fertility Land Management and Agroclimatology', (2008), Turkey [On-line]. Available: http://adudspace.adu.edu.tr:8080/jspui/ bitstream/11607/2647/1 /024.pdf [17 Feb 2018].

Wallace, J. S. 2000. Increasing agricultural water use efficiency to meet future food production. Agric. Ecosyst. Environ. 82: 105-110.

\section{How to cite this article:}

Shiva Kumar, R., T.K. Bridgit and Chanchala, A. 2018. Physical and Chemical Properties of Sandy Soil as Influenced by the Application of Hydrogel and Mulching in Maize (Zea mays L.). Int.J.Curr.Microbiol.App.Sci. 7(07): 3612-3618. doi: https://doi.org/10.20546/ijcmas.2018.707.420 